Article

\title{
Religion, Migration and Political Economy in the USA: from Open-Doors to Raids \& Sanctuaries
}

\author{
Antonio Sánchez-Bayón ${ }^{1, *}$ and Jesús J. Sánchez-Barricarte ${ }^{2}$ \\ 1 Universidad Rey Juan Carlos, Department of Applied Economics, 28032 Madrid; antonio.sbayon@urjc.es \\ 2 Universidad Carlos III, Department of Social Analysis, 28091 Getafe; jesusjavier.sanchez@uc3m.es \\ * Correspondence: antonio.sbayon@urjc.es
}

\begin{abstract}
This is a study of Political Economy on religion and migration management in the United States of America (USA). This paper offers a review of migrants-citizens relations in the USA, with attention to the pendulum effect, moving from integration policies (open doors and melting pot agenda) to official persecution (raids and deportations), with a high social opportunity cost. There has been a split between the State and civil society, causing civil disobedience and sanctuary network across the country. Also, it is paid attention to the American post-modern paradox, as a result of culture wars and identity politics that imply a violation of American constitutional principles (i.e. religious liberty, freedom of movement, to pursuit the happiness). Special attention is paid to the development of the Sanctuary Movement, as an ongoing example of the sociocultural upheaval bringing grassroots society into confrontation with powerful elites by promoting resistance and offering help to the needy, even if this results in sanctions. This movement was revitalized after the values crisis of 2008, but it has also been polarized between those who follow the traditional approach to socio-religious action in the form of peaceful civil disobedience, and those who follow the ideological anti-system and communitarian approach, which causes greater tension for the immigrants themselves
\end{abstract}

Keywords: Religion; migration; Political Economy; demographic economic policies; sanctuary movement; persecution; civil disobedience; The United States of America (USA/US).

\section{Introduction: detecting social problems in USA}

It has now been four centuries since the first European migrants arrived in the USA, in New England, in search of religious liberty and freedom of movement, and also to establish new settlements (Rothbard, 1975-79. Sánchez-Bayón, 2008-13). The arrival of this anniversary highlights the stark difference between then and the current social problems in relation to migration: why do the descendants of the migrants of yesteryear reject migration today? And particularly, why does this happen amongst White Anglo-Saxon Protestants (WASPs)? (Baltzell, 1962, 1964, 1979). Why do public authorities, who should guarantee America's foundational principles (religious liberty and freedom of movement are written into the Declaration of Independence and in the Bill of Rights) violate these principles? Both federal powers and many state powers enforce raids and deportations under the premise of criminal law rather than administrative law. And how can diversity be integrated if the former civic melting pot model is attacked in favor of community identity policies that aim to promote differences? (Both defenders and detractors of immigration coincide in rejecting the melting pot model, which was functional during the 20th century, without offering a feasible alternative, see Steinfield, 1975. Hirschman, 1983). How can a new citizenship born of migration be integrated when we have been immersed in a deep identity and sociocultural crisis since the culture wars? (Sánchez-Bayón, 2016, 2019. Yarnold, 1999, 2000). Identity politics has meant that the rights of minorities in the US are promoted more than ever, but they are done so at a moment 
when these same rights are completely restricted to migrants, leaving them with barely any alternatives for integration into citizenship, which is questioned, and which implies the need to belong to a minority that can shelter them, e.g., one based on ethnocultural, sexual or gender aspects (Lilla, 2017. Fukuyama, 2018). Confronted with this overall confusion, this paper will address one key concept: that of the Sanctuary Movement. Though its name evokes a medieval period the USA never experienced, it fits quite well within the longstanding American tradition of socio-religious movements, social crusades and civil disobedience (Mateus et al., 2019. Valero et al., 2018, 2020). Depending on how these movements are managed, they could lead to a new cycle of awakenings and revivals (CAR) or to a worsening of the polarization that characterizes the current identity crisis (Sánchez-Bayón, 2019a).

If we had to find a starting point for the current problem, one phenomenon to take into account is the brain drain which occurred during the interwar period but also particularly after WWII. The social conflict fostered by the hybridization of the two main communitarian ideologies (socialism and nationalism) had destroyed Europe. Moreover, though it is true that these regimes were defeated, their legitimizing intellectual underpinning was not. Because the USA had a strong desire to proclaim itself the champion of the West, it considered it acceptable to risk attracting the European intelligentsia of that time without previously subjecting it to a process of Americanization: the belief at the time was that this massive inflow into universities, media and think-tanks would help to increase America's scientific-academic capital. It was also believed that this could be used as part of the postmodern critique of Europe, without realizing that this would eventually lead to the deconstruction of the USA itself (Americanless. Sánchez-Bayón, 2019a \& b). This has led to the American postmodern paradox, which, as part of its process of deconstruction and deepening of its citizens' identity crisis, fosters the violation of the USA's foundational principles, without offering a clear substitute (with the disappearance of the WASP model, what could replace it, and how would this operate?). Meanwhile, one citizens' response has emerged through the Sanctuary Movement: a movement against injustice that has a religious origin (this is typical of the USA, where socio-religious movements and the crusades associated with them have played a key role in transforming social order throughout history). This movement has experienced a recent revitalization in the wake of the 2008 crisis of values, but it has also been impacted by the American postmodern paradox, which has caused internal divisions and conflicts (between those very socio-religious groups who center around peaceful civil disobedience, and who would rather toe the traditional line, and the anti-system and communitarian ideologues, who seek conflict). There is also an externalization of this conflict: both in migrant communities, by forcing them to choose between citizenship or community; and among the rest of the population, making them choose between helping their equals or violating the existing order.

\section{Theoretical framework y methodology applied}

This paper is part of a bigger research agenda, with the support of some publication in other languages (Sánchez-Bayón, 2018, 2019b. Mateus et al, 2018. Valero et al, 2018, 2020). In this occasion, the current paper is a critical and comparative socio-historical review, with a cross-disciplinary approach (Church-State Studies, Migration Studies, Political Economy, Law \& Economics, etc.). The main theoretical framework comes from the School of Chicago (a pioneer in cross-disciplinary studies) and its influence on new disciplines (from the 70s, i.e. Religion $\mathcal{E}$ Geography, Religion $\mathcal{E}$ Economics). The aim of this paper is to review the development of the US migrant-citizen relation, and to explain hermeneutic turn: from a common open-doors policy to a divided situation, between public raids and private sanctuaries.

In terms of the current state of research, the attention is focused on native scientific-academic research (only American literature, leaving out foreign research). In particular, the bibliography from the area of Cultural Studies is used, which is intrinsically 
linked to the influence of religious factors on religious citizen-migrant relations (such is the case, for example, with Church-State Studies $\mathcal{E}$ Migration Studies). It should also be mentioned that, though traditionally we consider the state of research to be the most recent bibliography (usually published in the last five years and determined by the limits of available knowledge), given the temporal-spatial coordinates and object of this research, and its critical-comparative and revisionist hermeneutic nature, we have concentrated our attention on the most relevant production since the consolidation of Cultural Studies up until globalization (determining impact as the number of citations of a given work and its presence in syllabi for courses taught in the aforementioned disciplines). The selection of readings which inspire this work fit into three groups: a) School of Chicago (throughout all its generations and heirs, both through primary and secondary sources); b) Sociology of religion and migration (from pioneers such as Emerson and his disciples, the pragmatists James, Dewey, etc., through the mentioned School of Chicago, with all its generations and followers up to its revitalization during the culture wars since the 1960s by Bellah, Berger, Demerath, etc.; c) Cultural Studies (Church-State Studies E Migration Studies).

In order to understand the recurring social phenomenon through which US civil society can be mobilized to reclaim the rights of the dispossessed (in this instance, migrants) and/or oppose domestic public policies and regulations considered unfair (putting their own freedom on the line), we must consider various research strands which tend to interweave and overlap:

- Political theology and Cultural Studies: as opposed to traditional Theology, which focuses on the knowledge of God, modern or political Theology focuses on the organization and salvation of God's people. In the USA, thanks to modern secularization and the support of political theology, great advances have been made towards a new novus ordo seculorum (this being one of the great national slogans; The Great Seal, 1782). This is shaped (much like other national slogans, i.e. Annuit coeptis, 'in God we trust'), by social constructs such as American civil religion-ACR (which allows the cohabitation of traditional religions but also integrates them under a formula for citizenship which predates the 19th century European concept of nation); American social Gospel-ASG (a social evangelism which promotes the concern and betterment of the common good, with crusades to transform American society on its path to progress and wellbeing); and American Covenant Theology-ACT (which serves as the base for its social contract and institutional development). This political theology (which inspires other manifestations, such as American manifest destiny-AMD or American self-righteousness-ASR), has influenced the USA's development (both domestically and internationally), even inspiring its self-proclamation as the champion of the West (after WWII). Cultural Studies, a discipline that has developed since the end of the 19th century (particularly in Divinity Schools and Arts and Humanities Colleges), they have provided a historical-comparative perspective, which changed throughout the interwar period, focusing on the study of American singularity and the establishment of its idiosyncrasy (on which the religious factor has had a relevant influence). This concept was maintained until the culture wars (1960-80), when new Cultural Studies-NCS (which were nurtured by the post war brain drain, and did not go through an Americanization process), they took on post-modern veils of confusion and were protected by both the 1972 federal law and affirmative action funds right up until the appearance of identity politics. Since then, religion has gone from being a social sphere of relevance (one which facilitated vision, mission and values) to becoming one which is contingent to each community and therefore yet another element of difference and social conflict (there are even NCS which refocus the issue as one of "racial justice"). In terms of issues related to theology and religious studies, one of the first veils that appeared was that of the new age theology of religion and spirituality. Since then, traditional religions and American civil religion (ACR), they have been abandoned, giving way to political religion as a sustaining force for the moral superiority of the weak thought of one single vocation. 
Cross-Cultural Studies (Political-Legal-Economic Sociology and Cultural Studies): ever since America's origins there has been a keen interest in social order and its legality (the legitimacy, validity and effectiveness of norms and institutions) as well as in issues relating to values and principles, the common good, and political-legal culture. Because of this the USA has been a pioneer in providing formulas and politico-legal sociological schools: it has been so since the pro-religious liberty and freedom of conscience reformist puritan movement of the pre-colonial period, represented by Revs Williams, Penn, etc; as well as the pro-abolitionist Mennonite and Quaker movements; passing through the 19th century transcendentalist movement and the related acts of civil disobedience, with theologians and proto-sociologists such as Emerson, Thoreau et al.; as well as the Methodist and Quaker movements with their commitment to abolition and suffrage (i.e. Anthony, Stanton, Bloomer); up until more recent movements (in the interwar period) such as American legal realism and its social test (i.e. Holmes, Pound, Frank); or civil rights movements and their non-violence resistance (i.e. Rev T. D. Jemison, Rev. M. Luther King Jr.). But the sociological and legal-humanist tradition is even older amongst Americans: from the first generations of colonial pilgrims and puritans, with their transition from their Blue Laws to Chartism to the Bill of Rights (from tolerance to freedom and to the Bill of Rights from the thirteen original colonies), through the political theologians who started the network of American universities (i.e. Rev. Prof. S. Stoddard, grandfather of Edwards, and the Mathers in New England of the 18th Century; W. Ames and S. Davies, at Princeton University, in the Middle Provinces of 18th Century; G. Whitefield, W. Tennent, S. Johnson and J. Edwards, who promoted the new Ivy League universities, as a proto-Enlightenment of the thirteen colonies, and inspiration for the First Great Awakening of the 1730s, etc.) followed by the creators or framers (Franklin, Adams, Jefferson, Paine, et al.) with their Declaration of Independence (1776) and Bill of Rights (1789), passing through the previously mentioned transcendentalists (leaded by Rev. Emerson, Whitman, etc.) and their civil disobedience (Thoreau, 1849); reaching the recent civil liberties movements (during the 1960s for African Americans, in the 1980s for Latin Americans, etc.). In terms of Cultural Studies (much as with political theology), after leaving behind the comparative-historical perspective, there was a refocusing on the idiosyncratic elements of the USA, which led to the tension and polarization between Traditional Cultural Studies-TCS (based on ethos-logos and of a consensual nature) and NCS (with a conflictive nature and conceptualized according to pathos-mythos). Amongst the latest attempts by TCS to reformulate a legal-political sociology of consensus we must highlight the revival of American exceptionalism from comparativists and geopolitical theorists such as Lipset (1963, 1996), Huntington (2004), etc., or cultural analysts such as Almond and Verba (1963), or even economists such as Rothbard (1975-79, 1995) or Posner (1973).

- Other contributions of those approaches, attended in this paper, they are the various constructs to understand and to manage the complex and fickle American social reality: from its American Awakenings $\mathcal{E}$ Revivals theory (AAR or CAR: cycles of awakenings \& revivals) to its proposals of denominationalism (which is essential to understand solidarity and social movements in the USA), ecumenism (to understand interconfessional initiatives, such as the sanctuary movement), and its ACR (with ASG, AMD, etc). Amongst the innovators in this area during the mid-20th century it can highlight Blau (1946,1952), Eliade (1961, 1971, 1978), Mannheim (1950), Stokes (1950), Dawson (1953), Wood (1961), etc.; and amongst its defenders during the culture wars it can cited Bell (1960, 1976), Bellah (1970, 1975, 1987), Berger (1967, 1969, 1974, 1979), Bloom (1992), etc. Amongst TCS, we must highlight the role of Church-State Studies as a pioneer of the American relational model, based on separation by accommodation, as established by the First Amendment (with a guaranteed aconfessional approach: a lower limit or (non)establishment clause, and an upper or free-exercise clause); without forgetting the famous wall of separation between Church and State (based on autonomy and non-interference) which supports the idea of sanctuary (from the 19th century underground railroad cases that aided slaves escaping to abolitionist states). Amongst the thousands of researchers specializing in 
this area, it must highlight figures as Stokes (at Yale), Pfeffer (at NYU and Yeshiva University), Dawson, Wood and Davis (at Baylor and MHBU).

It is offered now an outline of the main US scientific-academic contributions on citizen-migrant relations, with particular focus on religious influence. First, the pioneer School of Chicago (with theories as marginal man or lonely migrant); secondly, the TCS review (with theories on the role of family migration and congregations welcoming, as it is the case of Sanctuary Movement, see later).

1) School of Chicago: a key contribution was the symbolic interactionism (from Mead to Blumer, as a new edition of the American pragmatism), which aims to interpret and manage the problems found in complex social realities, particularly those of Human Ecology in thriving Chicago. In 1910 it had a population of over 2 million, with two thirds of them from a migrant background, where communities integrated migrants (this happened particularly with religious communities, both because they were transversal and because national identities were not then as strong or binding). According to symbolic interactionism, behaviors depend on the meanings given to social life objects (symbols), which then vary according to each person's social experience (people select, use and transform symbols, in their interpretative processes and according to their intentions and expectations). So symbols condition communication and social capital, easing the solving of problems and the development of a social imagination (which allows us to understand, systematize and manage a rich social reality according to our vision, mission and values), which then, in turn, transforms social reality (Thomas' theorem: the belief that something is real makes it real in its consequences). Therefore, the religious communities were the best suited to study symbolic interactionism (as they have mastered the management of the social-me and the theorem already mentioned above), and as their desires for a better society lead them to spear crusades of social change, influencing both public opinion (through their concerns and narratives) and the institutional agenda (through public policies and regulation). In the School, also, there was a line of criminological studies, which understood that the religious factor was the key for restraining social deviations and achieving greater solidarity. From the first generation of the School, it must cite the theory of organization-disorganization-reorganization, which describes the processes that affect generations of migrants (religious factors ease the adaptation process and lay the basis for the theory of melting pot). The second generation introduced other elements for social analysis (and therefore migrant-citizen relations), such as racial, sexual/gender or migrant relations, influencing the social status and residence place (i.e. concentric zone model), as well as possible criminality (i.e. social disorganization theory). Adding to this, it no longer conceives of migration as the flux of groups, organized by imposed communities (family and religion), but rather sees it as an individual phenomenon, with a selection of support structures (both legal and illegal): this is the marginal man theory (Park, 1928. Stonequist, 1937. Goldberg, 1941). Within the third generation, it must highlight the following contributions (with elements of migrant-citizen relations): Anderson and The Hobo (1923); Thrasher and The Gang (1926); Wirth and The Ghetto (1928); Zorbaugh and The Gold Coast and the Slum (1929); Shaw and The Jackroller (1930); Cressey and The Taxi Dance Hall (1932); Fraizer and The Negro family (1932), et al.

2) TCS: it pays attention to one of the oldest disciplines, Church-State Studies, and one of the newest, Migration Studies.

a) Church-State Studies (CSS): there are many authors and proposals during its one century and half existence, so it is going to remark the contributions made by the post-war renewal generation, because of their resystematization of the discipline, conjointly covering various key concepts such as denominalism/confessionalism (solidarity and social mobility through religious groups), cycles of awakenings and revivals (the appearance of religious groups with social claims, leading to change in elites and institutions), religious freedom (as a human right and geopolitical issue), socio-religious care (supported by religious groups), etc.

b) Migration Studies: despite being a more recent discipline, the volume of scientific-academic work is larger. For this research we have focused on its revision of the 
melting pot theory (at least in its latest version: American exceptionalism. Lipset, 1996), from the perspective of multiculturalism (Naylor, 1998. Masur, 1999. Rodríguez, 2002). It has also focused on its research on models applied to citizen-migrant relations, particularly the current Sanctuary Movement model. At the same time, however, it divides itself into two currents (which tend to polarization and confrontation):

- Traditional Sanctuary Movement (TSM): born of the US-Mexican border. In 1982, the US states with the strongest hold were Texas and Arizona (where legal and judicial problems started to arise). Despite Central American travelers meeting the conditions for refugee status according to the 1980 Refugee Act, the Reagan Administration (specifically, the Immigration \& Naturalization Service-INS) did not grant it in first instance (perhaps because of geopolitical interests), leading to the extremes of controversial cases such as US v. Aguilar (883 F. 2d 662). TSM responded to the USA's long tradition of the American Social Gospel-ASG, as part of its idiosyncrasy (i.e., examining how religion has worked both as social cement and as motor and raising agent). This is studied in TCS, which has considered social transformation crusades, in which the social bases seek to achieve the common good, justice and the improvement of the system through civil disobedience and nonviolent resistance (Godar, 1986; Tomsho, 1987; Altemus, 1988; Crittendon, 1988: Pirie, 1990).

- New Sanctuary Movement (NSM): it is influenced by the concepts presented by NCS (Hondagneu-Sotelo, 2007. Hagan, 2010. Wild, 2010. Caminero-Santagelo, 2013. Meirowitz, 2017) so it is no longer about spontaneous voluntary movements with a religious conscience which aim for the common good, but rather, there is a leadership made up of professional and well-organized activists, with new slogans (i.e. social and racial justice, moral indignation) that emphasize differences and conflict and carry certain contradictions (i.e. the fight for pacifism), as well as with innovative approaches and revolutionary subjects (i.e. Muslims, women, the environment, the media). A proof of this change is the manifesto for a Global Sanctuary Movement or Sanctuary Planet (based on a network of coalition networks), promoted by the interuniversity project Society and Space (led by the University of Washington).

Combining all of the above, after a critical historical-comparative and hermeneutic revision, this paper offers a holistic study of migrant-citizen relations which clarifies the following: what the main cycles of socio-religious awakenings and revivals have been. These have allowed for the reception and integration of different waves of migration, thanks to the solidarity and mobility fostered by religious movements (with their settlements, crusades, etc.), and given the concern and influence of the institutional agenda and its regulation of models of typification (i.e. openness and the American dream, WASP preference, restriction of quotas for non-WASPs). It is important to examine why these typifying models for migrant-citizen relations have changed over time and whether the blurring of religious factors has had something to do with it (i.e. the fall of migration by religious communities in favor of the migration of the marginal man). Also, why there has been a divergence between social demands and institutional responses by the power elites in the model of migrant-citizen relations up until the current model. On the one hand, we find an official model of persecution and deportation within the framework of public identity politics policies (which over-represent minorities), and on the other hand we find the protest network-sanctuary unofficial model. At the same time, because of the division within this model (TSM vs NSM), and analyzing its network (i.e. organization, speeches, actions), we hope to diagnose and predict which faction will end up as dominant (depending largely on the support provided by Cultural Studies, also divided between TCS -pro TSM- vs. NCS pro NSM), and through this to resolve the postmodern American paradox (linked, amongst other aspects, to the identity crisis, the decline of WASPs and the lack of a clear replacement). If TSM-TCS ends up dominating, it is possible that a fifth cycle of awakening and revival will occur, in which religion once again will become a key element for social transformation and migration becomes a key social element. If, however, NSM-NCS ends up dominating, it is possible we will have another intense social conflict (as happens every three or four generations, i.e. the War of Independence, 
the Civil War, the Hispano-American War, the World Wars. Howe \& Strauss, 1991, 1993, 1997).

This is, in essence, the aims to study the fate of the USA according to its citizen-migrant relations, and with the connecting thread of religion, which is one of the most important elements causing social tension and one of the least covered (at least, if compared to other classic differentiated cleavages, such as rural-urban, Church-State, employer-employee distinctions, etc. Lipset \& Rokkan, 1957).

\section{Case study: Sanctuary Movement}

In Law, even more than in any other technical or professional languge, it is crucial to use the relevant terminology with rigour and precision. For this reason, there is an examination of socio-religious activism, its development and its cost, in the relations between migration and citizenship in the USA (Wiltfang et al, 1991), it is essential to understand the legal basis for this institution. A "sanctuary" means both the religious building where the pilgrim and/or persecuted individual can take refuge, the charitable practice of safeguarding and granting safe conduct, and the medieval legal institution that forms the basis for the law of asylum. This is the result of a merger between Roman/Canon Law (asylum), and Germanic Law (shrine or santuary/hörgr or altar), which survived in vestigial form in Anglo-American Common Law (grith or refuge), until it was revived in modern times by socio-religious movements in the USA with their practices of civil disobedience and non-violent resistance in the course of their campaigns for social justice. In this way, in United States culture at the dawn of post-globalization a pre-modern concept of seeking protection through the sacred has been combined with post-modern information technology and social networks to revitalize modern citizens committed to civil liberties (through means of organization under the auspices of social movement that do not seek power in itself, but rather aim to improve the system (hence their CAR, see below, rectifying injustices through campaigns aimed at transforming society).

This study focuses on the revitalization of the sanctuary movement (SM). This is an inter-confessional initiative in US civil society that arose in the 1980s (with the growing movement pursuing civil liberties for the Hispanic population) and was reactivated after the crisis in values in 2008. It is a way of offering refuge to persecuted immigrants in the USA, through a network of over a thousand organizations throughout the country. It can be seen as a further case of heteropraxis (a heterogeneous religiosity oriented towards action that is promoted through grass roots communities as a way of exercizing their social evangelism), in consonance with the long US tradition of CAR to promote the common good and social justice through non-violent civil resistance to transform the social order. Its main objectives and campaigns are set forth here (these are now usually conducted through internet and social networks), taking into account the risks and responsibilities taken on by the people who form part of the movement, the administrative sanctions imposed on the organization, and the detention of around fifty members (around one third of whom are ministers of religion).

In the Western religious tradition (which has deeply influenced political theology in the USA), there are many passages in the Scripture, that not only recognise the status of sanctuary, but also promote it as one of the practical imperatives or works of charity. In the western secular tradition, there has also been broad recognition of this institution (partly within the framework of Church-State relations), through which different jurisdictions were understood to exist in the different spheres: if someone was persecuted by civil justice and took refuge in a church or monastery (this rule was later extended to cover universities), he/she could ask for sanctuary and thus come under church jurisdiction. Various traditions have taken root in the USA, acquiring an "American" character, which became important in the great crusades to transform American society over the centuries:

a) foundational period (CAR1: 1620-1791): sanctuary was used to refer to each new colony of dissidents founded on the frontier to offer protection to people who were persecuted (see Rev. R. Williams in Rhode Island, Rev. W. Penn in Pennsylvania); these were the distant ancestors of the later sanctuary-towns. 
b) re-foundational period (CAR2: 1820-1880): sanctuary was the abolitionist network (underground railroad) that took in runaway slaves; women's role in this was such that it also served to promote the suffragist cause (the Beecher: 1841, 1852, 1869, 1870, 1873).

c) hegemonic period (CAR3: 1890-1950): sanctuary was any socio-religious centre that provided healthcare and other services to the community (i.e. education, healthcare, accommodation, support in cases of addiction).

d) period of decline (CAR4: 1960-90): sanctuary could be from any of the socio-religious centre mentioned, or even sanctuary towns or campuses (e.g. against conscription for the wars in South-East Asia, particularly Vietnam); it is in CAR4 that the SM proper came about, to give asylum to immigrants from Central America who were fleeing wars and dictatorships in their own countries (particularly, those coming from El Salvador, Guatemala and Honduras).

At present, with the revitalization and reformulation of the SM, it is not clear yet if it is part of the fifth CAR or a major social conflict that will transform the USA (Howe \& Strauss, 1991, 1993, 1997). What is clear is that the SM is experiencing a boom, in reaction to the Trump Administration (compared with his predecessors), since his policies against undocumented migrants (particularly Hispanic Catholic migration), are perceived to be even more unjust (because the "wall"). The reaction of the civil society is the opposite: against the raids, there are many examples of sanctuary protection (i.e. a Hispanic migrant with leukemia in Shadow Rock United Church of Christ in Phoenix, in February 2018, a Mexican in the Methodist Church of Philadelphia in October 2017, a migrant from El Salvador in the First Unitarian Church in Austin in September 2017, a Guatemalan woman in the Pentecostal Church of God in New Haven in August 2017, etc.). With Biden Administration, there is expectation for changes in public policies, but it is not clear yet.

There is now a development evaluation and a diagnosis and prognosis of SM. The movement began on the border with Mexico, and in 1982 it was most widespread in Texas and Arizona (where legal problems and lawsuits soon arose). It turned out that the fugitives from Central America, despite fulfilling all the conditions to be declared refugees (in accordance with the federal Refugee Act of 1980), the Reagan administration (through its agency the Immigration $\mathcal{E}$ Naturalization Service-INS) did not initially accept this (perhaps because of geopolitical interests in the region), and polemical legal cases were heard such as United States v. Aguilar (883 F. 2d 662). In 1982, INS agents infiltrated the SM (operation sojourner), resulting in 71 criminal and administrative charges against 16 people ( 3 nuns, 2 priests, 1 pastor and volunteers in various congregations), as well as the arrest of 53 Central Americans accused of collaborating with the network throughout the country (in Phoenix, Seattle, Tucson, Philadelphia and Rochester). The trial was held in 1985, under conditions that were unfavourable to the defence: the use of terms like "refugee", "murder", "torture" or "enforced disappearance" was forbidden, and the use of the international regulation ratified by the USA and its federal law of 1980 was also refused; in the end, only 8 of the defendants were convicted, on 18 charges. As a result of the popular indignation throughout the trial, the SM grew exponentially, beyond the religious movements, spreading to the whole of civil society, with the addition of new categories such as sanctuary city or sanctuary campus, as well as other protected groups (i.e. boat people) and causes (i.e. pacifism and non-intervention in Latin America). Although it took over a decade to change the regulations and public policies, the cultural battle had been won, and the movement now had support in the form of public opinion. There was now popular sympathy for the cause and backing for the dreamers (as the Central Americans sheltered by the civil rights movement came to be known, in allusion to American Dream-AD).

From the original SM (in the early 1980s), with its calls to civil disobedience and to aid the needy, as was the case in the Catholic diocese of Tucson and the Presbyterian and Unitarian congregations of the area (which, like many others, had been infiltrated by the INS, and whose members were to pay a high price before proving the injustice of the system and bringing about change), by the late 1980s there was already a sound network of collaboration with over 500 organizations across the country (Tucson, Phoenix, El Paso, San Antonio, San Diego, Los Angeles, Las Cruces, Chicago, Boston, New York, 
Washington DC, etc.). Their activities extended to providing lodging, providing medical attention, teaching English, providing transport in private vehicles, helping people to obtain employment, and so on. In the early 1990s, with the advent of globalization, not only did the situation for regulating asylum for refugees improve, but there was also a certain openness to immigration (at least, since new means of entry became possible, such as by air), and the USA even became a place of transit for entry into Canada, where the SM also gained ground. During this boom period (the happy 1990s), the SM dispersed somewhat, as it seemed that the desired social change had been achieved. However, in the 2000s this situation was reversed: after 9/11 and the recession, the regulation of immigration again became a hot issue, with an increase in restrictions and the start of large-scale deportations. At the same time, in Central America, the conditions were again ripe for a new migratory wave. This time, it was inspired by denominalism (related to the pull effect of the dreamers' success story), and appealed to young people with dismal prospects in their countries of origin. In the years running up to the crisis of 2008, the multinationals were cutting back in Central America (with massive redundancies for unqualified workers and the closure of many subsidiaries), at the same time as corruption and violence were coming to the fore and populist regimes were again taking control (i.e. the return of Ortega and "sandinism regimen" -with the motto: "Catholicism, socialism and solidarity"- in Nicaragua in 2006, which has lasted until today, dragging the GDP down to one third of its former value and situating the country among the poorest three in Latin America, next to Honduras and El Salvador, according to data from BIRD, CEPAL and the World Bank, without mentioning the massive failures in Haiti and Venezuela). Under the contradictory Obama Administration (with the highest indices of deportations (over 400,000 cases per year from 2011 to 2015), and the ICE -formerly INS- carrying out large number of raids, at the same time as regulations were approved such as DACA, DAPA and the Executive Action restricting police action, or state legislation was criticised (see Arizona's SB 1070: Support Our Law Enforcement and Safe Neighborhoods Act of 2010 - described as a hate law), the movement was relaunched under the name of the New Sanctuary Movement (NSM). From the SM to the NSM there were many changes (not just the name, but also the stance towards various issues, actions, etc.), because the social reality itself had changed, with its public policies and regulations. Then, with the Trump Administration (from late 2016, even before he took possession), there was a U-turn on migration issues: restrictions on police action were overturned (particularly concerning raids and deportations), new policies were enforced limiting immigration and refusing refugee status to people who had fled from violence or persecution in their countries of origin (for example, Syrians fleeing from persecution).

The NSM, from its relaunch onwards, was no longer one social movement among many, but developed into a network of digitally integrated coalition networks. This network included the following organizations that descended from the original SM: Austin Sanctuary Network, Boston NSM, SLC Sanctuary Network, Colorado Springs Sanctuary Coalition, Metro Denver Sanctuary Coalition, Columbia County Sanctuary Coalition, IMIrJ, Interfaith Movement of Human Integrity, NSM New York, NSM Philadelphia, and others. But it also included new groupings: a) migration activists, such as Mijente, \#Not1More Deportation, Cosecha, United We Dream, National Day Labor Organizing Network, Fair Immigration, etc.; b) Muslim organizations, such as MPower Change, Muslims for Social Justice, CAIR, Shoulder to Shoulder, etc.; c) racial justice groups: Black Lives Matter, Showing Up for Racial Justice, etc.; and d) organizations providing legal support, i.e. UUA, UUSC and UUCSJ, ACLU, The National Lawyers Guild, etc. This came to constitute a collective movement taking in around one thousand organizations, hundreds of platforms and channels, and thousands of collaborators, in which people did not merely share support for a cause, but became equipped to bring about social change.

In a comparison in the development of SM: is there a continuity between TSM and NSM or there are many mutations? TSM emerged from the long-standing American tradition of American social Gospel-ASG (a reflection of American idiosyncrasy and studied as such by the TCS), with its campaigns for social transformation, promoted at grass roots level in favour of the common good, justice and improving the system, by means of civil disobedience and non-violent resistance (Godar, 1986. Tomsho, 1987. 
Altemus, 1988. Crittendon, 1988. Pirie, 1990. Coutin, 1993). By contrast, the NSM is influenced by the assumptions of the NCS (Caminero, 2009. Freedland and Stud, 2010. Hagan, J., et al. 2010. Paik, 2017. Ridgley, 2008): this is no longer a spontaneous movement undertaken by volunteers with a religious consciousness seeking the common good. Instead, there are professional, well-organised activists who provide leadership under new slogans (such as social and racial justice or moral indignation) -exalting difference and conflict, and thereby falling into certain contradictions, such as the "struggle" for pacifism, as well as innovative ideas and revolutionary subjects (i.e. Muslims, women, the environment, the media). Proof of this change is the manifesto for a global sanctuary movement, or Sanctuary Planet (based on a network of coalitions), driven by the inter-university project Society and Space (led by the University of Washington, Carney et al, 2017):

"We offer here a Manifesto for radical action: the formation of a Global Sanctuary Collective. Sanctuary was a powerful movement of resistance against Reagan's policies towards migrants fleeing repressive regimes in Central America who were supported by the US. Originally a faith-based movement inspired by the peace and justice ethos of churches and synagogues in the US, sanctuary became a powerful grassroots movement against egregious government policies toward Central America. Today with Trump we may be witnessing a resurgence of the moral outrage and political activism that fueled the Central America peace movement in the 1980s - actions by those willing to openly confront the equally damaging policies against refugees and undocumented migrants, as well as his harmful remarks and destructive actions against Muslims, women, the environment, and the media, among others. Moral outrage, in this context, is the feelings and expressions of disparate people who witness injustices compounded over time and committed in the name of the nation, and who collectively rise up against them. It is a spontaneous but also resilient emotional awareness, one that we believe is once again being galvanized in the current moment. [...] We conclude with a discussion of future directions for sanctuaries and a manifesto for a Global Sanctuary Collective to defend the rights of refugees, undocumented immigrants, and immigrants from any nationality, race, or religion. The new Global Sanctuary Collective builds on and expands the work of faith-based organizations, where sanctuary began, and calls on the creative forces of all people to turn moral outrage into protection of the vulnerable, protest against injustice, creative expression of human values and dignity, and collective action for social justice and human rights of all people, including immigrants"' (Carney et al, 2017).

Figure 1: Sanctuary movement network (churches and religious/social centers)

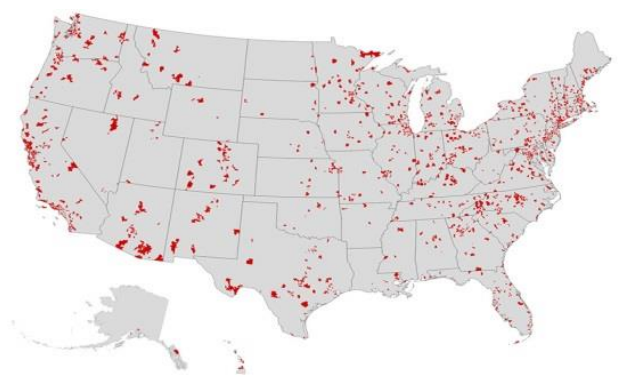

Sources: Church World Service \& Groundswell, 2017

\section{Discussion and conclusions}

The comparison between TSM and NSM is very complex, for this reason, in this paper is just paid attention to the changes resulting from the use of IT in the NSM's actions, from its platforms and channels to the campaigns and some instances where these were successful. The NSM activists are highly competent, no longer reactive volunteers but rather proactive leaders: they receive training via internet (i.e. webinars, instructional clips, downloable toolkits $\mathcal{E}$ reports), to run social networks and channels (i.e. Facebook, Twitter, Whatsapp), taking advantages of tools and communities (i.e. Groundswell, Actionnetwork, BitLy), and open-source software (i.e. Gmail, Dropbox), so that they are constantly connect- 
ed, and can organise actions and events at any moment (e.g. concentrations, vigils, press releases), receiving ample publicity and spreading the word through blogs and newsletters, as well as receiving legal advice in real time (from ACLU, UUA, or The National Lawyers Guild). Among the many resources of the NSM, to coordinate their communication and events, specific webpages and networks are important, such as National Sanctuary Movement, Sanctuary Coalition and Sanctuarynotdeportation. These websites bring together the main documents and resources needed, as well as advice on organizing events, communicating with the public, giving press conferences, etc.

At the same time, the audio-visual resources provided by the NSM are very rich and varied, especially those that tell the stories of migrants who have been given sanctuary. These are examples of LIMBIC communication, since they not only provide statistics, but also tell the stories of people and their families that people can identify with, as well as stories that can be shared in order to call for action. Many cases of NSM campaigns are to be found in various platforms (e.g. New Sanctuary Coalition, Sanctuary not Deportation, National Sanctuary Movement), which shed light on the way the NSM manages its resources and social networks to achieve support with a view to putting an end to raids and deportations.

To make a diagnosis with the basis of this paper, it is necessary to remember the changes with the globalization and the paradigm shift: there is a transition from an old World dominated by the nation-State to one new that is intensely interconnected. This need for balance and reformulation holds for all countries, particularly those that are most exposed, such as the hegemonic powers like the USA, which proclaimed itself the leader of the West after WWII (Fukuyama, 1989, 1992). This explains its identity crisis, which not only affects its own citizens, but also influences the relations between citizens and migration. If to all this we add the attacks on the foundations of its principles of integration during the culture wars (from the baby-boomers onwards), the current confusion is hardly surprising - this can no longer be approached in terms of logos or rational-technical notions, but rather in terms of pathos or shared feelings. The result is the post-modern United States paradox, which has not only deepened the American identity crisis, but has also given rise to new violations of the country's foundational principles, as we have seen above.

One possible solution to the sociocultural problem that this poses emerges from the sanctuary movement. This movement emerged from the US tradition of helping one's neighbour and fighting for social justice, and has been led through the social and religious movements that have given rise to four major AAR. In its origins, the sanctuary movement could have been regarded as bearing the seeds of a potential fifth AAR, but after its revitalization (in the wake of the 2008 crisis of values) it became affected by the post-modern American paradox, giving rise to division and conflict: on the one hand, the TSM (the original way, following the US tradition of social crusades to improve the system), led by volunteers offering socio-religious support and responding to unjust migration by peaceful civil disobedience; and on the other, the NSM (following the turn that things took elsewhere in the 20th century, with neo- or post-Marxist undertones), with professional activists leading the social protest, characterised by aspects of weak thought (political correct- 
ness and inclusive language, a gender perspective), which is no longer necessarily related to religious movements, at least not Judeo-Christian ones.

For these reasons, depending on which side emerges as victorious from this struggle (for identity and collective mentality, the social imaginary and symbolic capital, etc., in short for the American (social) Gospel or "spirit" of the USA), we might be witnessing the start of a new CAR, or of a new social conflict (resulting from the end of the generational cycle: War of Independence, Civil War, etc.). What does appear clear (in the case of the sanctuary movement), is that it is going through a new period of reformulation alongside other social movements, with its call for civil liberties (social action, civil disobedience, conscientious objection, judicial activism, etc.). Nonetheless, it is somewhat doubtful (because of the division mentioned above), if this is only a revival of the call for more rights for Hispanics (as in the 1980s, in the case of the Central American dreamers whose descendants still influence migration policies today), or if this is another manifestation (not a movement seeking the extension of rights, but one of social confrontation: from the NCS and its deconstruction, it is driven under slogans reflecting the gender perspective, with talk of latinex to impose an inclusive language, which paradoxically divides those affected). Moreover, even if we accept that this is a further renewal of a civil liberties movement in the post-Judeo-Christian mode, with recognition of rights for migrant Muslim communities (like those stemming from the Arab Spring in 2010 and particularly the Syrian humanitarian crisis), this social action places a greater emphasis on the exaltation of difference (demanding privileges, not common rights) and the deconstruction of the foundations of civic integration (by denying the sacred US tradition and its civil religion or CAR). The issue continues to develop, without a clear objective, towards an improvement in citizen-migrant relations, since the migratory communities are in tension (within themselves and with each other), and so are the social bases and elites of the USA. This is where the situation currently stands, but it is important for all of us to follow the post-modern American paradox and its risk of trans-Westerness with the utmost interest.

Also, this kind of policies for migrant-citizen relations in the USA, they have a high social opportunity cost, because this country was founded by migrants and it needs migrants. The persecution, raids and deportation policies, they have a biggest social cost in the federal budgets (i.e. Trump Administration had to declare the federal lockout in 2017 and to stop the project of the border wall construction); at the same time, there is a social cost, because there is a biggest fracture between the elites (with this kind of policies) and the civil society, which supports the sanctuaries across the country. It is necessary to apply the public choice theory for this topic, to review the role of the Public Sector and the Public Finance.

Author Contributions: Conceptualization, A.S.B.; investigation, A.S.B., J.S.B.; writing-original draft preparation, A.S.B.; writing - review and editing, A.S.B., J.S.B.; supervision, A.S.B., J.S.B. All authors have read and agreed to the published version of the manuscript.

Funding: Not applicable.

Institutional Review Board Statement: Not applicable.

Informed Consent Statement: Not applicable. 
Data Availability Statement: Not applicable.

Acknowledgments: GESCE-URJC, GID-TICTAC CCEESS-URJC and TRANS-REAL LAB-UVA.

Conflicts of Interest: The authors declare no conflict of interest.

\section{References}

Almond, G., Verba, S. 1963. The Civic Culture. New York: Sage Publications.

Altemus, M. 1988. The Sanctuary Movement. Whittier Law Review, 9: 683-721.

Baltzell, E.D. 1962. An American Business Aristocracy, Philadelphia: Collier Books.

Baltzell, E.D. 1964. The Protestant Establishment. Aristocracy E Caste in America, New York: Random House.

Baltzell, E.D. 1979. Puritan Boston and Quaker Philadelphia: Two Protestant Ethics and the Spirit of Class Authority and Leadership, New York: Free Press.

Bell, D. 1960. The end of the ideology. New York: Free Press.

Bell, D. 1976. The cultural contradictions of capitalism. New York: Basic Books.

Bellah, R. 1970. Beyond beliefs: Essays on Religion in a Post-Traditional World. New York: Harper \& Row.

Bellah, R. 1975. The broken covenant: American Civil Religion in the Time of Trial. New York: The Seabury Press.

Bellah, R. 1987. Uncivil Religion: Interreligious Hostility in America, New York: Crossroad Publishing.

Berger, P. 1967. The Sacred Canopy: Elements of a Sociological Theory of Religion. Garden City: Doubleday.

Berger, P. 1969. A rumor of angels: Modern society and the rediscovery of the supernatural. Garden City: Doubleday.

Berger, P. 1974. Pyramids of Sacrifice: Political Ethics and Social Change. New York: Basic Books.

Berger, P. 1979. Facing Up to Modernity: Excursions in Society, Politics and Religion. New York: Basic Books.

Blau, J.L. 1946. American Philosophic Address, 1700-1900, New York: Columbia University Press.

Blau, J.L. 1952. Men and Movements in American Philosophy. Englewood Cliffs: Prentice-Hall.

Bloom, H. 1992. The American religion. The emergence of the Post-Christian Nation. New York: Simon \& Schuster.

Caminero-Santagelo, M. 2009. Responding to the Human Costs of US Immigration Policy: No More Deaths and the New Sanctuary Movement. Latino Studies, 7: 112-122.

Carney, M.A., Gomez, R., Mitchell, K., Vannini, S. 2007. Sanctuary Planet: A Global Sanctuary Movement for the Time of Trump, Society and Space Project-University of Washington (URL: Sanctuary Planet Society Space.pdf (washington.edu)).

Coutin, S.B. 1993. The Culture of Protest: Religious Activism and the U.S. Sanctuary Movement, Boulder: Westview Press.

Crittendon, A. 1988. Sanctuary: A Story of American Conscience and the Law in Collision, London: Weidenfeld.

Dawson, J.M. 1953. America's Way of Church, State, and Society, New York: MacMillan.

Eliade, M. 1961. The Sacred and the Profane: The Nature of Religion. New York: Harper.

Eliade, M. 1971. The Myth of the Eternal Return: Cosmos and History. Princeton: Princeton University Press.

Eliade, M., 1978. A History of Religious Ideas. Chicago: University of Chicago Press.

Freedland, G., Stud, L. 2010. Negotiating place, space and borders: The New Sanctuary Movement. Latino Studies, 8: $485-508$.

Fukuyama, F. 1989. The end of History? The National Interest, Summer: 1-18.

Fukuyama, F. 1992. The End of History and the Last Man. New York: Free Press.

Fukuyama, F. 2018. Identity: Contemporary Identity Politics and the Struggle for Recognition. New York: Farrar, Straus and Giroux.

Godar, J.F. 1986. The Sanctuary Movement: An Analysis of the Legal and Moral Questions Involved. St. Louis University Legal Journal, 30: 1221-1239.

Goldberg, M.M. 1941. A qualification of the marginal man theory. American Sociological Review, 6(1): 52-58.

Hagan, J., Rodriguez, N., Castro, B. 2010. Social effects of Mass Deportations by the United State Government: 2000-2010. Ethinic and Racial Studies, 34: 1374-1391. https://doi.org/10.1080/01419870.2011.575233

Hirschman, C. 1983. America's melting pot policy reconsidered, Annual Review of Sociology, 9: $397-423$.

Hondagneu-Sotelo, P. 2007, Religion and Social Justice for Immigrants, New Brunswick: Rutgers University Press.

Howe, N., Strauss, W. 1991. Generations: The History of America's Future, 1584 to 2069. New York: William Morrow \& Co.

Howe, N., Strauss, W. 1993. 13th Gen: Abort, Retry, Ignore, Fail? New York: Vintage Books.

Howe, N., Strauss, W. 1997. The Fourth Turning: What the Cycles of History Tell Us About America's Next Rendezvous with Destiny, New York: Broadway Books, 1997.

Huntington, S. 2004. Who Are We? The Challenges to America's National Identity, New York: Simon \& Schuster.

Lilla, M. 2017. Once and Future Liberal: After Identity Politics. New York: Harper Co.

Lipset, S.M. 1963. The First New Nation, New York: Basic Books.

Lipset, S.M. 1996. American excepcionalism. A double-edged sword. New York: W.W. Norton \& co.

Lipset, S.M., Rokkan, S. 1967. Party systems and voter alignments, New York: Free Press.

Mannheim, K. 1950. Freedom, Power, and Democratic Planning. New York: Oxford University Press. 
Masur, L.P. 1999. The Challenge of American History, Baltimore: John Hopkins Univ. Press.

Mateus, M.N., Sánchez-Bayón, A. 2019. Novas abordagens e fenómenos em estudos de imigração: movimentos religiosos no coração dos Estados Unidos da América, Journal of Sociology and Theory of Religion, 8: 45-82.

Meirowitz, L. 2017. A Jewish Guide to the New Sanctuary Movement, New York: T'ruah.

Naylor, L.L. 1998. American Culture: Myth and Reality of a Culture of Diversity, Westport: Bergin \& Garvey.

Paik, A.N. 2017. Abolitionist futures and the US sanctuary movement. Race E Class, 59: 3-25.

Park, R. 1928. Human Migration and the Marginal Man. American Journal of Sociology, 33: 881-893.

Pirie, S.H. 1990. The Origins of a Political Trial: The Sanctuary Movement and Political Justice. Yale Journal of Law E the Humanities, 2: 381-416.

Posner, R. 1973. Economic Analysis of Law. Boston: Little, Brown \& Co.

Ridgley, J. 2008. Cities of Refuge: Immigration Enforcement, Police, and the Insurgent Genealogies of Citizenship in U.S. Sanctuary Cities. Urban Geography, 29: 53-77.

Rodriguez, R. 2002. Brown: The Last Discovery of America. New York: Penguin Books.

Rothbard, M. 1975-79. Conceived in Liberty (4 vols.). New Rochelle: Arlington House Publishers.

Rothbard, M. 1995. An Austrian Perspective on the History of Economic Thought (2 vols.). Auburn: Mises Institute (2006).

Sánchez-Bayón, A. 2008-13. La Modernidad sin prejuicios. La religión en la vida pública estadounidense (3 vol.). Madrid: Delta Publicaciones.

Sánchez-Bayón, 2018. Estudio de la idiosincrasia estadounidense desde su Teología política y Ciencias Eclesiásticas. Estudios Eclesiásticos, 93(364): 165-204.

Sánchez-Bayón. A. 2019a. American identity crisis: attack to American civil religion \& trans-Westerness risk, Cogito, 11(1): 23-51.

Sánchez-Bayón, A. 2019b. Renovación de la Teología política y Sociología de la religión en la posglobalización: revitalización del movimiento santuario para inmigrantes en EE.UU. Carthaginensia, 35(68): 485-510.

Steinfield, M. 1973. Crack in the Melting pot. Racism and discrimination in American History, Beverly Hills: Glencoe Press.

Stokes, A.P. 1950. Church and State in the United States (3 vols.), New York: Harper.

Stonequist, E.V. 1937. The Marginal Man. A Study in Personality and Culture Conflict, New York: Charles Scribner's Sons.

Thoreau, H.D. 1849. Resistance to Civil Government or Civil Disobedience, in H.D. Thoreau: Aesthetic Papers. Boston: Putnam.

Tomsho, R. 1987. The American Sanctuary Movement, Austin: Texas Monthly Press.

Wood, J. 1961. Church and State. Waco: Baylor University Press, 1961.

Yarnold, B. 1999. Religious Wars in the Courts I. The lower federal courts and the US Supreme Court in Religious Freedom cases 1970-1990, Hintington: Nova Science Publishers, 1999.

Yarnold, B. 2000. Religious Wars in the Courts II. Who were the litigants in the US Courts, Religious Freedom cases 1970-1990, Hintington: Nova Science Publishers.

Valero, J., Sánchez-Bayón, A. 2018. Relaciones de la inmigración hispana con la Iglesia en el área de Washington D. C., Virginia y Maryland. Rev. Migraciones, 45: 89-117.

Valero, J., Sánchez-Bayón, A. 2020. Persecución religiosa y migratoria en la posglobalización: estudio del caso estadounidense y la deconstrucción de sus pilares fundacionales. Lurralde, 43: 61-88.

Wild, K.L. 2010. The New Sanctuary Movement: when moral mission means breaking the Law, and the consequences for churches and illegal immigrants. Santa Clara Law Review, 50: 981-1015.

Wiltfang, G.L., McAdam, D. 1991. The Costs and Risks of Social Activism: A Study of Sanctuary Movement Activism, Social Forces, 69: 987-1010. 